Research article

\title{
Human papillomavirus DNA in plasma of patients with cervical
}

\section{cancer}

\author{
Wichai Pornthanakasem ${ }^{1}$, Kanjana Shotelersuk ${ }^{2}$, Wichai \\ Termrungruanglert ${ }^{3}$, Narin Voravud ${ }^{4}$, Somchai Niruthisard ${ }^{3}$ and Apiwat \\ Mutirangura*5
}

\author{
Address: ${ }^{1}$ Department of Microbiology,, ${ }^{2}$ Department of Radialogy, Division of Radiation Oncology, ${ }^{3}$ Department of Obstetrics and \\ Gynecology,, ${ }^{4}$ Department of Medicine, Medical Oncology Unit, and ${ }^{5}$ Department of Anatomy, Faculty of Medicine, Chulalongkorn University, \\ Bangkok, Thailand \\ E-mail: Wichai Pornthanakasem - pornthanakasem_w@hotmail.com; Kanjana Shotelersuk - fmedvst@md2.md.chula.ac.th; \\ Wichai Termrungruanglert - fmed@md2.md.chula.ac.th; Narin Voravud - cu_medonco@hotmail.com; Somchai Niruthisard - \\ fmedsnr@md2.md.chula.ac.th; Apiwat Mutirangura* - mapiwat@chula.ac.th \\ ${ }^{*}$ Corresponding author
}

Published: 5 March 2001

BMC Cancer 2001, 1:2

This article is available from: http://www.biomedcentral.com//47/-2407/I/2

(c) 200 I Pornthanakasem et al, licensee BioMed Central Ltd.
Received: 31 January 2001

Accepted: 5 March 2001

\begin{abstract}
Background: Human papillomavirus (HPV) is a crucial etiological factor for cervical cancer (CC) development. From a diagnostic view-point, the consistent presence of HPV in CC allows the viral DNA to be used as a genetic marker. The aims of this study were to evaluate the presence, physical status and clinical significant of HPV DNA in circulation of CC patients.

Results: Whereas 6 out of 50 (I2\%) HPV positive CC patients revealed plasma HPV DNA, it was detected in none of 20 normal controls or 13 HPV negative CC cases. The plasma DNA exhibited an HPV type identical to the HPV in the primary tumors and the DNA from both sources was integrated into host genome. Interestingly, several findings suggested an association between plasma HPV DNA and metastasis. First, three of the HPV DNA positive cases were CC patients with clinical stage IVB or recurrence with distance metastases $(P=0.00 I, R R=15.67)$. Second, the amount of plasma HPV DNA from metastatic patients to be three times more than three other patients without metastases. Finally, the later cases had tendency to develop recurrence distant metastases within one year after complete treatment when compared with other HPV associated CC patients with the same stage but without the present of plasma HPV DNA.
\end{abstract}

Conclusions: The plasma HPV DNA originated from the $C C$, was associated with metastasis and could be used as a marker representing the circulating free CC DNA.

\section{Background}

Cervical cancer (CC) is one of the most common malignancies in women worldwide, especially in developing countries [1]. Several studies have suggested that human papillomavirus (HPV) initiates and causes endogenous genetic alterations in the progression of CC [2]. First, ep- idemiological studies have shown that most human CCs harbor the "high risk" HPV types 16, 18, 31 and 33 [3,4]. Second, some HPV proteins such as E6 and E7 interact with human tumor suppresser gene products and change cellular phenotypes [5]. Finally, the integration linearizes HPV DNA between E1 and L1 genes and dis- 
rupts the viral E2 gene, which consequently induces expression of E6 and E7 genes [6,7]. This genomic rearrangement is thought to be critical for the transformation and proliferation of the early precursors to these cancers [1 ]. From a diagnostic viewpoint, the consistent presence of HPV in CC allows the viral DNA to be used as a genetic marker. For example, cervical pre-malignant lesions can be screened for highly sensitive HPV DNA detection technology in cell scrapings [8].

Accumulating lines of evidence have elucidated that there is tumor DNA in patients' circulation. Such DNA can be detected in plasma or serum via specific genetic and epigenetic alterations of the primary tumor. Though the mechanism of this phenomenon is not clear, the presence of tumor DNA in blood may have diagnostic and prognostic value $[9,10,11,12]$. Interestingly, viral DNA has been documented to occur as tumor DNA in the circulation of patients with primary tumors caused by viral infection. For example, there is a high frequency of hepatitis viral genomes and Epstein-Barr viral (EBV) DNA in the circulation of patients with hepatoma and nasopharyngeal cancer (NPC), respectively $[13,14,15]$. In addition, the circulating EBV DNA may be an invaluable tool for patient monitoring $[15,16]$. Since HPV DNA serves as a genetic marker for $\mathrm{CC}$, we tested whether HPV DNA could be detected in the plasma of CC patients and whether it originated directly from tumor cells. Moreover, we determined whether the circulating HPV DNA has any diagnostic and prognostic clinical potential for patients with $\mathrm{CC}$.

\section{Materials and methods Sample Collection}

Primary CC tissues were collected from 63 patients before treatment at King Chulalongkorn Memorial Hospital. The tissues were divided into two parts. The first part was sent for routine histological examination. The second part was immediately stored in liquid nitrogen until further use. All of the tumors were histologically ascertained to be $\mathrm{CC}$ and the staging was done according to FIGO criteria. The 63 tumors included stages ranging from I to IV. All patients have been followed for treatment outcome and survival.

Blood samples were obtained by venipuncture from the same patients and 20 healthy blood donors. To obtain plasma, blood specimens in EDTA anticoagulant were centrifuged at $3,300 \mathrm{rpm}$ for $10 \mathrm{~min}$, and the plasma were stored at $-20^{\circ} \mathrm{C}$ before use.

\section{DNA Isolation}

$\mathrm{CC}$ tissue was treated with $\mathrm{SDS}$ and proteinase $\mathrm{K}$ at $50^{\circ} \mathrm{C}$ overnight, followed by phenol/chloroform extraction and ethanol precipitation of DNA. Plasma DNA was pu- rified on Qiagen columns (Qiamp blood kit; Qiagen, Basel, Switzerland) according to the "blood and body fluid protocol". Plasma (200 $\mu \mathrm{l})$ was processed using the column and one-tenth of the extracted DNA was then used for PCR analysis.

\section{HPV Detection, Quantitation and Typing}

For analysis of the HPV DNA in the plasma from CC patients, HPV E6 gene amplification was performed using a protocol previously described with some modifications [17]. The PCR reaction was in a total volume of $20 \mu \mathrm{l}$ containing $200 \mu \mathrm{M}$ of each dNTP, $10 \mu \mathrm{M}$ Tris- $\mathrm{HCl}(\mathrm{pH}$ 8.4), $50 \mathrm{mM}$ potassium chloride, $4.0 \mathrm{mM}$ magnesium chloride, 0.5 units of AmpliTaq Gold (Perkin Elmer Cetus), $0.4 \mu \mathrm{M}$ of WD76 (CGGTTSAACCGAAAMCGG) and WD67 (WGCAWATGGAWWGCYGTCTC), $0.1 \mu \mathrm{M}$ of WD66 (AGCATGCGGTATACTGTCTC), WD 72 (CGGTCGGGACCGAAAACGG) and WD154 (TCCGTGTGGTGTGTCGTCCC). Additionally, another PCR using $0.3 \mu \mathrm{M}$ of primers specific for $Z P_{3}$, a gene on the human $\mathrm{X}$ chromosome, were performed to test the quality of DNA [18]. For testing DNA and screening for HPV incidence, one $\mathrm{ZP}_{3}$ primer, and $\mathrm{WD}_{72}$ and $\mathrm{WD}_{76}$, respectively, were end labelled at $37^{\circ} \mathrm{C}$ for $1-2 \mathrm{~h}$ in a total volume of $10 \mu \mathrm{l}$ containing $10 \mu \mathrm{M}$ primer, $0.025 \mathrm{mCi}[\gamma-$ ${ }^{32} \mathrm{P}$ ] ATP (Amersham-Pharmacia) at $3000 \mathrm{Ci} \mathrm{mmol}^{-1}, 10$ $\mathrm{mM}$ magnesium chloride, $5 \mathrm{mM}$ DTT, $70 \mathrm{mM}$ Tris- $\mathrm{HCl}$ $(\mathrm{pH} 7.6)$ and 10 units of $\mathrm{T} 4$ polynucleotide kinase (New England Biolabs). Without further separating of the unincorporated nucleotides, the kinase reaction was added to the PCR buffer mix. The PCR amplifications were performed as follows: initial denaturation at $95^{\circ} \mathrm{C}$ for 10 min, followed by 40 cycles of denaturation at $95^{\circ} \mathrm{C}$ for 1 min, annealing at $55^{\circ} \mathrm{C}$ for $1 \mathrm{~min}$, extension at $72^{\circ} \mathrm{C}$ for 2 min and a final extension at $72^{\circ} \mathrm{C}$ for $7 \mathrm{~min}$. Reaction products were mixed with loading buffer and loaded onto a $4 \%$ non-denaturing polyacrylamide gel. DNA fragments were size fractionated at $800 \mathrm{~V}$ until the tracking dye had covered the appropriate distance of the gel. After electrophoresis, the wet gel was transferred to filter paper (Whatman), wrapped with Saran wrap and exposed to a phosphorus screen; the bands were visualized on PhosphoImager using ImageQuaNT software (Molecular Dynamics). E6 and ZP3 primer pairs yielded 243 and $177 \mathrm{bp}$ PCR products, respectively. For HPV typing, $50 \mu$ l of unlabeled PCR product was prepared for dot blot experiments. All HPV DNA positive plasma and some tumor DNA samples were measured semiquantitatively by performing duplex radiolabeled E6 and $\mathrm{ZP}_{3}$ primer PCR and repeating the above PCR reaction [18]. The difference between viral and host genome copy numbers was calculated from the relative intensity of PCR bands by the imageQuaNT software (Molecular Dynamics). 
Table I: Plasma HPV DNA in tumor, Clinical staging, and treatment outcome of $50 \mathrm{HPV}$ associated CC patients

\begin{tabular}{|c|c|c|c|c|c|}
\hline & & \multirow[t]{2}{*}{ Total } & \multicolumn{3}{|c|}{ Plasma HPV DNA } \\
\hline & & & Positive & & Negative \\
\hline Cervical Cancer patient & & 50 & 6 & & 44 \\
\hline \multicolumn{6}{|l|}{$\mathrm{Age}^{\mathrm{a}}$} \\
\hline & $<50$ & 25 & 3 & & 22 \\
\hline & $>50$ & 25 & 3 & & 22 \\
\hline \multicolumn{6}{|l|}{ HPV type } \\
\hline & $U^{b}$ & 4 & 0 & & 4 \\
\hline & 16 & 28 & 2 & & 26 \\
\hline & 18 & 16 & 4 & & 12 \\
\hline & 33 & 2 & 0 & & 2 \\
\hline \multicolumn{6}{|l|}{ Stage } \\
\hline & IB & 2 & 0 & & 2 \\
\hline & IIB & 17 & 3 & & 14 \\
\hline & IIIB & 28 & 0 & & 28 \\
\hline & IVB & 1 & I & & 0 \\
\hline & $\mathrm{R}^{\mathrm{c}}$ & 2 & 2 & & 0 \\
\hline \multicolumn{6}{|c|}{ IIB response to radiotherapy } \\
\hline & $P R^{d}$ & 3 & 2 & & 1 \\
\hline & $C R^{e}$ & 15 & 1 & & 13 \\
\hline \multirow{3}{*}{\multicolumn{6}{|c|}{$\begin{array}{l}\text { IIB clinical outcome within } \\
\text { one year after complete } \\
\text { treatment }\end{array}$}} \\
\hline & & & & & \\
\hline & & & & & \\
\hline $\mathrm{R}^{\mathrm{c}}$ & & 6 & 2 & & 4 \\
\hline $\mathrm{NED}^{f}$ & & 5 & 0 & & 5 \\
\hline \multicolumn{6}{|l|}{ Metastases } \\
\hline & Positive & 3 & 3 & $P=0001$ & 0 \\
\hline & Negative & 47 & 3 & $R R=15.67$ & 44 \\
\hline \multicolumn{6}{|l|}{ Histopathology type } \\
\hline & Squamous & 42 & 5 & & 37 \\
\hline & Adenomatous & 8 & I & & 7 \\
\hline
\end{tabular}

${ }^{a}<50$ and $>50$ age less than 50 , and above 50 , respectively; ${ }^{b} \mathrm{U}$, unknown; ${ }^{\mathrm{C}} \mathrm{R}$, recurrence: ${ }^{\mathrm{d}} \mathrm{PR}$, partial response; ${ }^{\mathrm{e}} \mathrm{CR}$, complete response; ${ }^{\mathrm{f}} \mathrm{NED}$, no evidence of disease

E6 type-specific probes were used for HPV typing. Positive controls of HPV type 6,11, 16, 18, 31 and 33 from each PCR amplification were included [17]. Products obtained from another unlabeled E6 PCR reaction were heated to $95^{\circ} \mathrm{C}$ and thereafter 1 volume of $20 \mathrm{X} \mathrm{SSC}$ was added. Aliquots of $40 \mu \mathrm{l}$ were applied to a Hybond- $\mathrm{N}^{+}$ nylon membrane (Amersham Pharmacia Biotech) under vacuum, prewetted in denaturing solution $(1.5 \mathrm{M} \mathrm{NaCl}$, $0.5 \mathrm{M} \mathrm{NaOH}$ ). The membranes were transferred to a filter paper soaked in neutralizing solution $(1.5 \mathrm{M} \mathrm{NaCl}$, $0.5 \mathrm{M}$ Tris- $\mathrm{HCl} \mathrm{pH} \mathrm{7.2,} 0.001 \mathrm{M}$ EDTA) for $1 \mathrm{~min}$. The membranes were air dried at room temperature, soaked in $0.4 \mathrm{M} \mathrm{NaOH}$ for $20 \mathrm{~min}$ for fixation and washed with $5 \mathrm{X}$ SSC. Prehybridization at $65^{\circ} \mathrm{C}$ for $1 \mathrm{~h}$ was carried out using 6 X SSC, 5 X Denhardt's solution, 0.5\% SDS and
$100 \mu \mathrm{g}$ of single-stranded sheared salmon sperm DNA per ml. Replicate membranes were separately hybridized with denatured ${ }^{32} \mathrm{P}$-labelled, type-specific probes in prehybridizing solution for $1 \mathrm{hr}$ at $55^{\circ} \mathrm{C}$. Probes WD170 (GCAAGACATAGAAATAA) required hybridization at $45^{\circ} \mathrm{C}$. Filters were rinsed briefly in $2 \mathrm{X} \mathrm{SCC}$ and $0.1 \%$ SDS at room temperature and then twice for $10 \mathrm{~min}$ at $45^{\circ} \mathrm{C}$ (WD170), 50-52 ${ }^{\circ} \mathrm{C}$ (WD132 (GACAGTATTGGAACTTACAG), RR1 (GTACTGCACGACTATGT) and RR2 (ACCTTTGCAACGATCTG)), $55-56^{\circ} \mathrm{C} \quad$ (WD103 (CAACAGTTACTGCGACG), WD165 (AAATCCTGCAGAAAGACCTC) and WD166(CCTACAGACGCCATGTTCA), or $56-57^{\circ} \mathrm{C}$ (WD133 (ACACCTAAAGGTCCTGTTTC) and WD134 (ACACTCTGCAAATTCAGTGC)). The membranes were exposed to a 
phosphorus screen and the signals were visualized on a PhosphoImager using ImageQuaNT software (Molecular Dynamics).

\section{Detection of HPV Integration by PCR}

All DNA samples from plasma and tissue that were positive for HPV type 16 and 18 were analyzed in two PCR reactions. One used $0.5 \mu \mathrm{M}$ of each primer (5' E2 consensus primer HPV-16/18 5'-ATGAAAATGAYAGTAMAGAC-3', 3' E2 primer HPV-16 5'-CCAGTAGACACTGTAATAG-3' and HPV-18 5'CATTGTCATGTATCCCACC- 3 '), with ${ }^{32} \mathrm{P}$-labelled HPV$16 / 18$ to detect 1026 and 1028 bp PCR products from HPV 16 and 18 episomal forms, respectively [7]. The other used $0.5 \mu \mathrm{M}$ of each primer of PIGR gene (PIGR-F $5^{\prime}-$ TCAGCCAGGGTAAGGATCC-3' and PIGR-R 5'-TGATGGTCACCGTTCTGCC-3') to amplify a 1392 bp fragment of human genomic DNA as a control. The PCR reactions contained $200 \mu \mathrm{M}$ dNTP each, $10 \mu \mathrm{M}$ Tris- $\mathrm{HCl}$ (pH 8.4), $50 \mathrm{mM}$ potassium chloride, $1.5 \mathrm{mM}$ magnesium chloride, 0.5 units of Thermus aquaticus DNA polymerase (Perkin Elmer Cetus), and the PCR amplifications were performed as follows: initial denaturation at $95^{\circ} \mathrm{C}$ for 5 min, followed by 40 cycles of denaturation at $95^{\circ} \mathrm{C}$ for 1 min, annealing at $45^{\circ} \mathrm{C}$ for E2 gene or $55^{\circ} \mathrm{C}$ forPIGR for $1 \mathrm{~min}$, extension at $72^{\circ} \mathrm{C}$ for $3 \mathrm{~min}$ and a final extension at $72^{\circ} \mathrm{C}$ for $7 \mathrm{~min}$. Reaction product was mixed with loading dye and loaded onto $4 \%$ non-denaturing polyacrylamide gel. DNA fragments were size fractionated at 800 $\mathrm{V}$ until the tracking dye had covered the appropriate distance of the gel. After electrophoresis, the wet gel was transferred to filter paper (Whatman), wrapped with Saran wrap and exposed to a phosphorus screen. The bands were visualized on a PhosphoImager using ImageQuaNT software (Molecular Dynamics).

\section{Correlation between Clinical Data and Plasma HPV DNA}

Data regarding histology, tumor staging, clinical phenotypes, treatment outcome, and HPV PCR and typing were collected in a double-blind fashion until analyzed. The Fisher's exact test was used to compare the results obtained from plasma analysis with those of HPV and clinical parameters.

\section{Results HPV DNA in Plasma}

To determine whether HPV DNA could be detected in the circulation of CC patients and represented tumor DNA, DNA from the plasma of three groups was studied. The first two comprised 63 positive and negative HPV CC patients, and the other 20 healthy female blood donors. The patients included in this study, were classified by age, pathological structure, and stage (Table 1). The control marker, ZP3, was positive in all samples. As a result, all were further analyzed for the presence of HPV DNA by PCR using labeled E6 degenerate primers. Plasma HPV DNA was a specific genetic marker for HPV associated $\mathrm{CC}$, since it was detectable from neither HPV negative CC nor normal controls. Nevertheless, the circulating DNA had low sensitivity. Only 6 out of 50 (12\%) with HPV associated CC patients were demonstrated to have circulating HPV DNA (Fig 1A and Table 1).

The frequency and type of HPV DNA were reevaluated from all plasma and tumor samples by PCR using the E6 degenerate primers and dot blot hybridization using type specific oligonucleotides (Fig 1B and Table 1,2). The presence of HPV DNA status was confirmed and plasma HPV DNA showed the same viral type as the tumors. Furthermore, DNA from both plasma and tumor from the 6 plasma-positive cases were differentiated between integrated and episomal. Since the integration process disrupts the HPV E2 gene, PCR using radioactive labeled E2 primer would show positive result from episomal form of HPV but negative if the DNA integrated (Fig 1C). Whereas E2 PCR product was detectable in $20.75 \%$ of the HPV positive tumors, none of the plasma or tumor samples from plasma HPV DNA positive CC patients was positive (Fig 1D). In consideration with the absence of episomal HPV DNA from tumor, it is most likely that the negative E2 PCR result was due to plasma HPV DNA derived from integrated HPV genome. This observation suggested that the circulating free HPV DNA originated from the $\mathrm{CC}$ and thus could be used as a marker for tumor DNA.

\section{Plasma HPV DNA and Clinical Correlation}

To elucidate the importance and meaning of CC DNA present in plasma, the correlation between the presence and amount of plasma HPV DNA and clinical data was investigated (Table 1). Clinical data including age, staging, metastasis, response to treatment, and site of recurrence of plasma HPV DNA positive patients were included inTable 2. Interestingly, there was an association between plasma HPV DNA and metastasis. Three out of six plasma HPV DNA positive patients but none of the other patients with HPV associated cancers had distant metastasis at the time of blood analysis $(\mathrm{P}<0.001$, $R R=15.67(5.24<R R<46.83))$. One of the three was stage IVB and two had a recurrence distant metastasis, one of whom had previously been plasma HPV DNA negative at stage IIIB. In addition, we evaluated the amount of HPV DNA in circulation by semi-quantitative PCR, comparing the intensity of PCR products between HPV E6 gene and $Z P_{3}$, a gene on the human X chromosome. The average intensity ratio between these two bands from tumor DNA and plasma DNA samples was one and 0.08 , respectively (Fig $1 \mathrm{E}$ and Table 2). Plasma from one of the patients, 106, was collected twice at dif- 

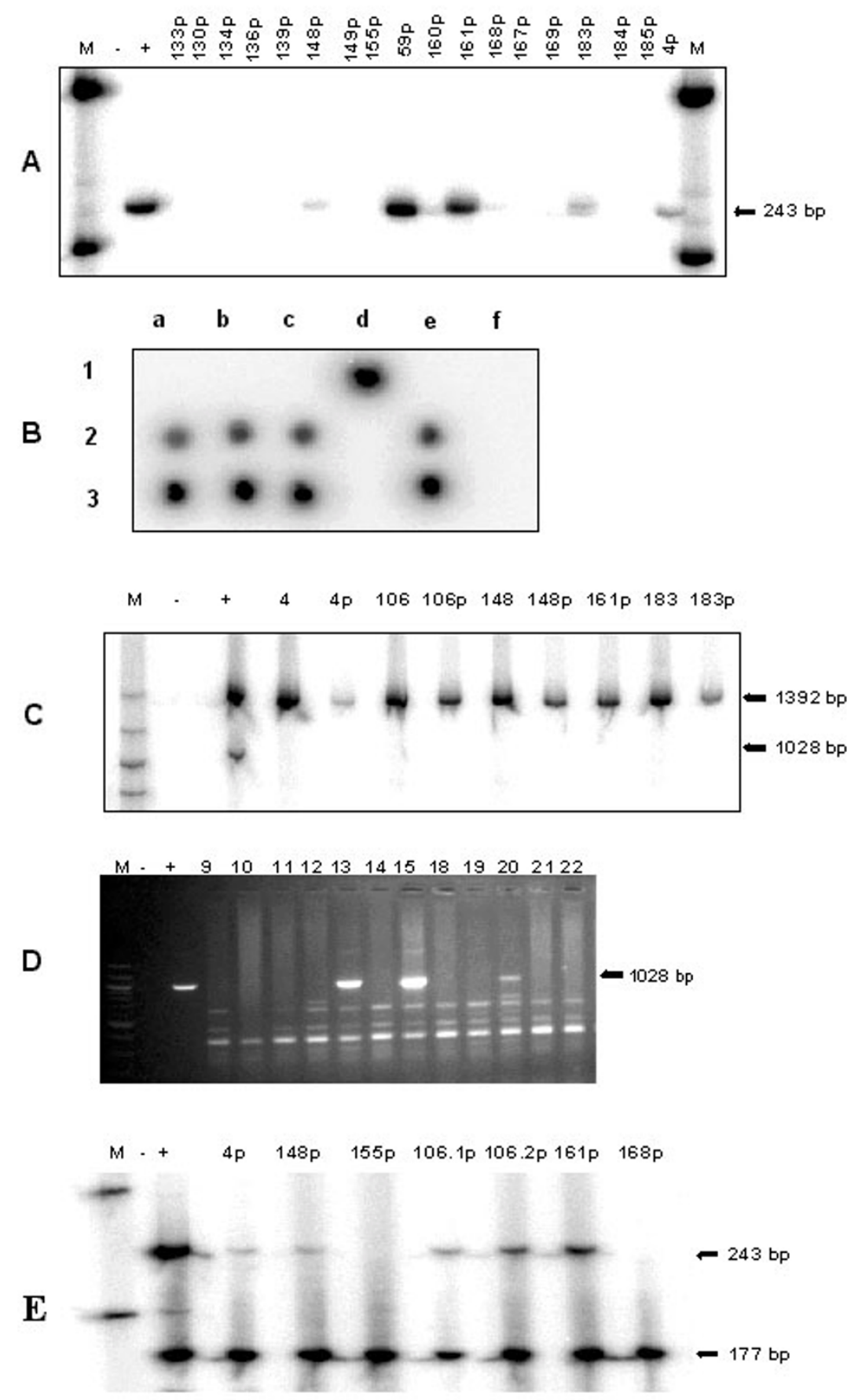

\section{Figure I}

HPV DNA in plasma of patients with cervical cancer. (A) PCR generating 243-bp DNA fragments of HPV E6 gene (B) Dot-blot hybridization for HPV 18 probe Lanes a l-fl were positive controls using purified plasmids of HPV type $6,11,16,18$, $3 \mathrm{I}$ and 33, respectively Lanes a2-f2 were plasma DNA from patients number 4, 106, 148, I6I, 183, and 59 respectively Lanes a3-f3 were tumor DNA from the same patients as lanes a2-f2 (C) PCR generating 1392- and 1028-bp DNA fragments of human PIGR genomic sequence and HPV-18 E2 (D) PCR generating 1026, 1028-bp DNA fragments of HPV 16 and I8 E2 gene, respectively, from tumor DNA on a $2 \%$ agarose gel stained with ethidium bromide (E) Duplex PCR generating 243- and I77bP DNA fragments of HPV E6 gene and human ZP3 genomic sequence, respectively From left to right of $A$, C-E: M, 100-bP ladder standard DNA size marker; - and +, PCR products of the negative control (double-distilled water) and positive control (Hela cell line for A and E; purified plasmids for D; and for C, DNA from human leukocyte for PIGR and purified HPV I8 DNA plasmid for E2 gene), respectively; numbers without $P$ indicate PCR products of tumor DNA; numbers with $P$ indicate PCR products of plasma DNA of CC patients Number 106Ip and 1062p were plasma DNA from patient 106 but the samples were collected at different time 
ferent time and demonstrated the identical ratio (Fig $1 \mathrm{E})$. Furthermore, the ratios from the three plasma samples of patients with metastases, 0.05, 0.14, and 0.19, was higher, though not statistically significant, $\mathrm{p}=$ 0.098 , than from the other three non-metastasis patients, 0.02, 0.04, and 0.05. Interestingly, the three plasma HPV DNA positive patients who were stage IIB did not have as good a clinical outcome when compared with the other plasma HPV DNA negative patients with the same stage. Whereas 13 out of 14 plasma negative cases had a complete response to radiotherapy, 2 out of the 3 circulating viral DNA positive cases were partially resistant. However, formal comparison did not yet show significant statistical value, $p=0.063$. In addition, we found that plasma HPV DNA positive patients may have tendency to develop recurrent disease. In patients who was followed up for more than one year, 2 out of 2 and 4 out of 9 plasma HPV DNA positive and negative patients, respectively, suffered reappearance of CC.

\section{Discussion}

The results of the present investigation confirm that it is possible to identify HPV DNA in DNA extracted from the plasma of patients with CC. More importantly, there are at least three findings suggesting that the viral DNA most likely originates from the tumor itself. First, circulating HPV DNA was not present in normal controls or HPV negative CC. In addition, all HPV DNA derived from HPV-associated CC patients' circulation was type 16 or 18 . These high-risk HPV types are frequently associated with high-grade cervical intraepithelial neoplasia and CC $[4,19]$. Second, the plasma DNA exhibited an HPV type identical to the primary tumors in the patients. Thus the possibility that HPV DNA in circulation is derived from another latent epithelial infection was remote. Finally, the HPV genomes from both tumor and plasma were revealed the same physical status by inte- grating into the host genome. This was a unique characteristic for CC development and confirmed that the circulating viral DNA was from cancer cells $[6,7]$.

Though both NPC and CC are viral associated lymphoepithelioma, squamous epithelial tumor with heavily lymphocyte infiltration, the incidence and physical status of viral DNA in the circulation and in tumors suggests that the DNA is released into the circulation of NPC and CC patients via a different mechanism. A much higher frequency of circulating EBV DNA has been discovered in NPC $[15,16]$. In addition, serum EBV DNA is resistant to Dnase treatment [15]. In conjunction with the expression and high antibody titer of lytic replication genes in NPC patients, it is likely that some circulating EBV DNA in NPC is virion associated $[15,20,21]$. In contrast to $\mathrm{EBV}$, at least two lines of evidences indicated that plasma HPV DNA was free DNA, not virion-associated. First, the clinical phenotype associated with circulating DNA was similar between head and neck squamous cell cancer (HNSCC) and CC. A recent study used human promotor hypermethylation as a serum marker and demonstrated an association between this epigenetic marker and metastasis [22]. In addition, circulating HPV DNA could be found in a low percentage and associate with metastasis not only of CC cases but also of HNSCC cases where the primary tumor harbors HPV DNA [23]. The other reason that argues against the possibility that circulating HPV DNA is virion-associated is that the viral genome has integrated into the host genome with consequent deletion of part of the HPV genome. This physical characteristic is unique to HPV carcinogenesis and prevents viral ability to undergo complete lytic replication. All this evidence suggested that the mechanism by which viral DNA is released into the circulation of NPC and CC, although both are viral associated squamous epithelial cancers, is distinct.

Table 2: Clinical parameters and HPV characteristics of 6 plasma HPV DNA positive CC patients

\begin{tabular}{|c|c|c|c|c|c|c|c|c|c|}
\hline $\begin{array}{l}\text { Patient } \\
\text { Code }\end{array}$ & Age & Stage $^{a}$ & $\begin{array}{l}\text { Pathology } \\
\text { Type }\end{array}$ & $\begin{array}{l}\text { Tumor } \\
\text { Size } \\
(\mathrm{cm})\end{array}$ & $\begin{array}{l}\text { Response to } \\
\text { Radiotherapy }\end{array}$ & $\begin{array}{c}\text { Time } \\
\text { Recur } \\
\text { (month) }\end{array}$ & $\begin{array}{l}\text { Metastatic } \\
\text { Organ }\end{array}$ & $\begin{array}{l}\text { HPV } \\
\text { type }\end{array}$ & $\begin{array}{c}\text { Relative } \\
\text { amount of } \\
\text { E6:ZP3 } \\
\text { PCR }^{f}\end{array}$ \\
\hline 4 & 39 & IIB & Adenomatous & 7 & Partial & & & 18 & 0.02 \\
\hline 148 & 65 & IIB & Squamous & 3 & Complete & 8 & $\begin{array}{c}\text { Pleura, } \\
\text { Peritoneumc }\end{array}$ & 18 & 0.04 \\
\hline 183 & 27 & IIB & Squamous & 6 & Partial & 11 & Bone ${ }^{c}$ & 18 & 0.05 \\
\hline 106 & 51 & IVB & Squamous & $>4$ & & & Liver, Pleurad & 18 & 0.14 \\
\hline 161 & 34 & $R^{e}$ & Squamous & 7 & & & Umbillicus ${ }^{d}$ & 16 & 0.19 \\
\hline 59 & 46 & $R^{e}$ & Squamous & 5 & & & Liver, Lung ${ }^{d}$ & 16 & 0.05 \\
\hline
\end{tabular}

\footnotetext{
${ }^{a}$ Stage at the time of blood examination; ${ }^{b}$ Time for recurrence after complete treatment; ${ }^{c}$ Metastasis at time of recurrence; ${ }^{d}$ Metastasis at time of plasma DNA analysis; ${ }^{e} \mathrm{R}$, recurrence; ${ }^{f}$ Average amount from two experiments
} 
This study indicated that plasma HPV DNA was a specific, but not a sensitive, genetic marker for $\mathrm{CC}$ diagnosis. More importantly, there was a strong association between plasma HPV DNA and metastasis, both when considering incidence and amount of the circulating viral DNA. Plasma HPV DNA positive non-metastatic CC patients had tendency toward poor clinical outcome and development of recurrent distant metastasis. This was not surprising. Although a variety of studies have shown that patients with very early stage disease can harbor free circulating tumor DNA, several reports have revealed plasma tumor DNA to be more commonly detectable in advanced stage disease, to correlate inversely with clinical outcome and to correlate with a tendency to fail with effective treatment $[9,22,23,24,25,26]$. There were at least three possible explanations for the association between plasma CC DNA and metastasis. The most common hypothesis is that circulating cancer DNA due to the lysis of circulating cancer cells or micrometastasis shed by the tumor. HPV-specific mRNA has been found in peripheral blood cells, circulating micrometastatic CC cells, and lymph nodes of advanced-stage CC patients with metastasis $[27,28]$. Nevertheless, a study of the relative amount of DNA in the plasma of pancreatic cancer patients indicated that a number of circulating cancer cells was insufficient and rejected this hypothesis [29]. Second, some in vitro and vivo studies have suggested that circulating tumor DNA in plasma might play a role in metastasis because of its high transforming activity $[30,31]$. Finally, because there is a tendency toward poor clinical outcome for plasma HPV DNA positive CC patients, the mechanism to actively release tumor DNA into circulation might occur late during the multistep process of CC development when metastasis is more likely [10]. Regardless of the mechanisms, our data show that plasma HPV DNA in viral associated CC should be an independent genetic marker to predict disease progression and clinical outcome.

\section{Conclusions}

The results of the present investigation indicated that it was possible to identify HPV DNA in DNA extracted from the plasma of some patients with CC. More importantly, The HPV genomes from both tumor and plasma were revealed the same type and physical status by integrating into the host genome. Thus the viral DNA most likely originated from the tumor itself and the plasma HPV DNA represented the circulating free cell CC DNA. Finally, plasma HPV DNA was a specific, but not a sensitive, genetic marker in which strongly associated with CC metastasis.

\section{Acknowledgements}

We are indebted to all staffs in the Department of Obstetrics and Gynecology and the Division of Radiation Oncology, Department of Radiology, Chulalongkorn University Hospital, who provided all clinical samples; and to Ms Sairoong Sakdikul for technical assistance. This work was supported by the Molecular Biology Project, Faculty of Medicine, Chulalongkorn University, and the Thailand Research Fund.

\section{References}

I. Cannistra SA, Niloff JM: Cancer of the uterine cervix. N Engl J Med 1996, 334:1030-1038

2. Lazo PA: The molecular genetics of cervical carcinoma. $\mathrm{Br} J$ Cancer 1999, 80:2008-2018

3. Bosch FX, Manos MM, Munoz N, Sherman M, Jansen AM, Peto J, Schiffman MH, Moreno V, Kurman R, Shah KV: Prevalence of human papillomavirus in cervical cancer: a worldwide perspective International biological study on cervical cancer (IBSCC) Study Group. J Natl Cancer Inst 1995, 87:796-802

4. Schiffman MH, Bauer HM, Hoover RN, Glass AG, Cadell DM, Rush BB, Scott DR, Sherman ME, Kurman RJ, Wacholder S, Stanton CK, Manos MM: Epidemiologic evidence showing that human papillomavirus infection causes most cervical intraepithelial neoplasia. J Natl Cancer Inst 1993, 85:958-964

5. Kubbutant MHG, Vousden KH: Role of E6 and E7 oncoproteins in HPV-induced anogenital malignancies. Semin Virol 1996, 7:295-304

6. Baker CC, Phelps WC, Lindgren V, Braun MJ, Gonda MA, Howley PM: Structural and transcriptional analysis of human papillomavirus type 16 sequences in cervical carcinoma cell lines. J Virol | 987, 6 1:962-97|

7. Park JS, Hwang ES, Park SN, Ahn HK, Um SJ, Kim CJ, Kim SJ, Namkoong SE: Physical status and expression of HPV genes in cervical cancers. Gynecol Oncol 1997, 65:121-129

8. Cuzick J: Human papillomavirus testing for primary cervical cancer screening. JAMA 2000, 283:108-109

9. Sidransky D: Circulating DNA: What we know and what we need to learn. Ann N Y Acad Sci 2000, 906: I-4

10. Stroun M, Maurice P, Vasioukhin V, Lyautey J, Lederrey C, Lefort F, Rossier A, Chen XQ, Anker P: The origin and mechanism of circulating DNA. Ann N Y Acad Sci 2000, 906:161-168

II. Jen J, Wu L, Sidransky D: An overview on the isolation and analysis of circulating tumor DNA in plasma and serum. Ann N Y Acad Sci 2000, 906:8-12

12. Anker $\mathrm{P}$, Mulcahy $\mathrm{H}$, Chen $\mathrm{XQ}$, Stroun M: Detection of circulating tumour DNA in the blood (plasma/serum) of cancer patients. Cancer Metastasis Rev 1999, I 8:65-73

13. Mutirangura A, Pornthanakasem W, Theamboonlers A, Sriuranpong V, Lertsanguansinchi P, Yenrudi S, Voravud N, Supiyaphun P, Poovorawan $Y$ : Epstein-Barr viral DNA in serum of patients with nasopharyngeal carcinoma. Clin Cancer Res 1998, 4:665-669

14. Tangkijvanich P, Hirsch P, Theamboonlers A, Nuchprayoon I, Poovorawan $Y$ : Association of hepatitis viruses with hepatocellular carcinoma in Thailand. J Gastroenterol 1999, 34:227-233

15. Shotelersuk K, Khorprasert C, Sakdikul S, Pornthanakasem W, Voravud N, Mutirangura A: Epstein-Barr virus DNA in serum/plasma as a tumor marker for nasopharyngeal cancer. Clin Cancer Res 2000, 6:1046-105 I

16. Lo YM, Chan LY, Lo KW, Leung SF, Zhang J, Chan AT, Lee JC, Hjelm NM, Johnson PJ, Huang DP: Quantitative analysis of cell-free Epstein-Barr virus DNA in plasma of patients with nasopharyngeal carcinoma. Cancer Res 1999, 59:1 I88-II91

17. Resnick RM, Cornelissen MT, Wright DK, Eichinger GH, Fox HS, ter Schegget J, Manos MM: Detection and typing of human papillomavirus in archival cervical cancer specimens by DNA amplification with consensus primers. J Natl Cancer Inst 1990, 82: | 477-| 484

18. Cui KH, Warnes GM, Jeffrey R, Matthews CD: Sex determination of preimplantation embryos by human testis-determininggene amplification. Lancet 1994, 343:79-82

19. de Villiers EM: Heterogeneity of the human papillomavirus group. J Virol 1989, 63:4898-4903

20. Martel-Renoir D, Grunewald V, Touitou R, Schwaab G, Joab I: Qualitative analysis of the expression of Epstein-Barr virus lytic genes in nasopharyngeal carcinoma biopsies. J Gen Virol 1995, 76: $1401-8$

21. Joab I, Nicolas JC, Schwaab G, de-Thoe G, Clausse B, Perricaudet M, Zeng $Y$ : Detection of anti-Epstein-Barr-virus transactivator (ZEBRA) antibodies in sera from patients with nasopharyngeal carcinoma. Int J Cancer I991, 48:647-649 
22. Sanchez-Cespedes M, Esteller M, Wu L, Nawroz-Danish H, Yoo GH, Koch WM, Jen J, Herman JG, Sidransky D: Gene promoter hypermethylation in tumors and serum of head and neck cancer patients. Cancer Res 2000, 60:892-5

23. Caone RB, Pai SI, Koch WM, Gillison ML, Danish HN, Westra WH, Daniel R, Shah KV, Sidransky D: Detection and quantitation of human papillomavirus (HPV) DNA in the sera of patients with HPV-associated head and neck squamous cell carcinoma. Clin Cancer Res 2000, 6:41 7/ -5

24. Fujiwara $Y$, Chi DD, Wang $H$, Keleman $P$, Morton DL, Turner R, Hoon DS: Plasma DNA microsatellites as tumor-specific markers and indicators of tumor progression in melanoma patients. Cancer Res 1999, 59:1567-157|

25. Silva JM, Dominguez G, Garcia JM, Gonzalez R, Villanueva MJ, Navarro F, Provencio M, San Martin S, Espana P, Bonilla F: Presence of tumor DNA in plasma of breast cancer patients: clinicopathological correlations. Cancer Res 1999, 59:325 I-3256

26. Yamada T, Nakamori S, Ohzato H, Oshima S, Aoki T, Higaki N, Sugimoto K, Akagi K, Fujiwara Y, Nishisho I, Sakon M, Gotoh M, Monden $M$ : Detection of K-ras gene mutations in plasma DNA of patients with pancreatic adenocarcinoma: correlation with clinicopathological features. Clin Cancer Res 1998, 4:1527-32

27. Pao CC, Hor JJ, Yang FP, Lin CY, Tseng CJ: Detection of human papillomavirus mRNA and cervical cancer cells in peripheral blood of cervical cancer patients with metastasis. J Clin Oncol 1997, I 5:1008-1012

28. Czegledy J, losif C, Hansson BG, Evander M, Gergely L, Wadell G: Can a test for E6/E7 transcripts of human papillomavirus type 16 serve as a diagnostic tool for the detection of micrometastasis in cervical cancer? Int J Cancer. 1995, 64:2 II-5

29. Sorenson GD, Porter DM, Barth RJ, Memoli VA, Rhodes CH, Karagas $M$, Tosteson TD, Bzik DJ: Detection of mutated KRAS2 sequences in plasma from patients with pancreatic carcinoma in comparison with the Cal 9-9 assay. J Int Soc Oncodev Biol Med 1997, 18:66-

30. Anker P, Lyautey J, Lefort F, Lederrey C, Stroun M: Transformation of NIH/3T3 cells and SW 480 cells displaying K-ras mutation. C R Acad Sci III 1 994, 317:869-74

31. Garcia-Olmo D, Garcia-Olmo DC, Ontanon J, Martinez E, Vallejo M: Tumor DNA circulating in the plasma might play a role in metastasis: the hypothesis of the genometastasis. Histopathol 1999, 4:1159-1164

\section{Pre-publication history}

The pre-publication history for this paper can be accessed here:

http://www.biomedcentral.com/content/backmatter/ 1471-2407-1-2-b1.pdf

\section{Publish with BioMedcentral and every} scientist can read your work free of charge

"BioMedcentral will be the most significant development for disseminating the results of biomedical research in our lifetime."

$$
\text { Paul Nurse, Director-General, Imperial Cancer Research Fund }
$$

Publish with BMc and your research papers will be:

- available free of charge to the entire biomedical community

- peer reviewed and published immediately upon acceptance

- cited in PubMed and archived on PubMed Central

- yours - you keep the copyright

Submit your manuscript here:

http://www.biomedcentral.com/manuscript/

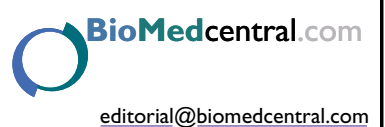

